\section{RICYDE. Revista Internacional de Ciencias del Deporte} doi: $10.5232 /$ ricyde

Rev. int. cienc. deporte

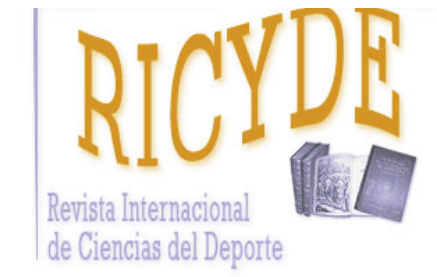

RICYDE. Revista Internacional de Ciencias del Deporte VOLUMEN XIII - AÑO XIII

Páginas:139-148 ISSN : 1885 - 3137

Número 48 - Abril - 2017

\title{
Stroke performance in high-level Spanish wheelchair tennis players Rendimiento del golpeo en jugadores españoles de tenis en silla de ruedas de alto nivel
}

\author{
Alejandro Sánchez-Pay1,2, Gema Torres-Luque2,3, David Sanz-Rivas ${ }^{4}$
}

1. Faculty of Sport Sciences, University of Murcia, Murcia, Spain.

2. Research group "Ciencia y Deporte SEJ460", Spain.

3. Faculty of Humanities and Education Sciences, University of Jaen, Spain.

4. Royal Spanish Tennis Federation.

\begin{abstract}
The aim of this study was to analyse shot selection in a wheelchair tennis (WT) tournament, comparing winning and losing players and evaluating the outcome of strokes. Sixteen men's singles WT matches (comprising a total of 5,720 strokes) were analysed. Each match was recorded and the following variables were analysed: services, returns, groundstrokes and net shots. Additionally, all strokes were coded according to type of point (non-game point opportunity, NGO; game point opportunity, GO), outcome (error; rally; winner) and set outcome (winner; loser). A Z-test was used to assess differences between winning and losing players and between NGOs and GOs. The results showed that WT players make more errors (19\%) than winning strokes $(10.6 \%)$. Service and return shots make up about $55 \%$ of shots played during a point and volleys and smashes are infrequent $(2.1 \%)$. Winning players hit more winners on service, return and groundstrokes than losing players. At the net losing players hit more winners than winning players, although they also made more errors. The critical situation (GO) could be not affect on game actions of WT points. These results and the differences between performances should be taken into consideration by wheelchair tennis coaches.
\end{abstract}

Key words: match analysis, adapted racket sports, and tennis shots.

\section{Resumen}

El objetivo de este estudio fue conocer los tipos de golpeo en un torneo de tenis en silla de ruedas (WT), observar las diferencias entre ganadores y perdedores, y evaluar su resultado. Se analizaron 16 partidos individuales, con un total de 5720 golpes. Cada partido fue grabado y analizado en base a las siguientes variables: saques, restos, golpes de fondo y golpes de red. Además, cada golpeo fue codificado con el tipo de punto (sin oportunidad de ganar el juego -NGO-, o con oportunidad de ganar el juego-GO), con el resultado del golpeo (error, peloteo, o golpe ganador), y el resultado del set (ganador y perdedor). Se utilizó el test Z para comparar las diferencias entre ganadores y perdedores, así como las diferencias entre NGO y GO. Los resultados muestran que el jugador de WT realiza más errores $(16 \%)$ que golpes ganadores $(10,6 \%)$. Los golpes de saque y resto representan cerca del $55 \%$ del total de golpeos en un punto, y las voleas y remates no son frecuentes durante el punto $(2,1 \%)$. Los jugadores ganadores hacen más golpes ganadores en saques, restos y golpes de fondo que los perdedores. En los golpes de red, los perdedores hacen más golpes ganadores que los jugadores ganadores, aunque también mayor número de errores. La situación de GO no parece afectar en las acciones de juego durante un punto en WT. Estos resultados deberían ser tomados en consideración por los entrenadores de tenis en silla de ruedas en los entrenamientos.

Palabras clave: análisis del partido, deportes de raqueta adaptados, golpeo de tenis.

Correspondence/correspondencia: Alejandro Sánchez-Pay

Facultad de Ciencias del Deporte. Universidad de Murcia, España

Email: aspay@um.es 
Sánchez-Pay, A.; Torres-Luque, G., \& Sanz-Rivas, D. (2017). Stroke performance in high-level Spanish wheelchair tennis players. RICYDE. Revista internacional de ciencias del deporte, 48(13), 139-148. https://doi.org/10.5232/ricyde2017.04804

\section{Introduction}

$\mathrm{W}$ heelchair tennis (WT) is an adapted sport; although it is played on a different surface from conventional tennis (CT) the general rules are the same. The main difference between CT and WT is that in WT the ball is permitted to bounce twice before being hit (ITF, 2012). There are now more than 140 international WT tournaments around the world (Bullock \& Sanz, 2010), so it is crucial that the level of competition is improved. To this end notational analysis is used to give provide data for technical and tactical evaluation, movement analysis, performance models and to improve the efficacy of training relationships (Hughes, 1998).

Analysis of competitions provides valuable information that allows us to define the technicaltactical demands the game makes on players (O'Donoghue, 2012). In the case of CT there have been some studies looking at differences between types of stroke used in competition (Johnson \& McHugh, 2006) and comparisons of the shots of winners and losers of matches (Brown \& O'Donoghue, 2008; Filipčič, Caks, \& Filipčič, 2011). It has also been shown that the distribution of technical actions is not invariant across a match, for example, it may change in a break point situation (Klaassen \& Magnus, 2001; Knight \& O'Donoghue, 2012).

Analyses of WT matches have provided information about the last shot in a point (Filipčič \& Filipčič, 2006; Sanchez-Pay, Torres-Luque, Cabello-Manrique, Sanz-Rivas, \& Palao, 2015a), but not which shots are repeated during a point. Filipčič and Filipčič (2006) showed that returns and groundstrokes make up the highest percentages of winners and errors in WT. Moreover, winning players win a higher percentage of points on first and second serve as well as winning a higher percentage of return and break points won and making more winning shots and fewer errors (Sánchez-Pay et al., 2015a).

The differences between CT and WT are highly visible. CT players have a greater displacement ability, greater ability to recover, higher contact with the ball and hit the ball harder than WT players (Cavedon, Zancanaro, \& Milanese, 2014; Filipčič \& Filipčič, 2009; Martínez-Gallego et al., 2013; Reid, Elliott, \& Alderson, 2007; Sindall et al., 2013). There are also important differences in the game statistics for CT and WT players: CT players win a higher percentage of points on their first serve, make fewer double faults, earn fewer break points and win fewer of them (Sánchez-Pay, Palao, Torres-Luque, \& Sanz-Rivas, 2015b).

Information on shots and performance can help to improve the quality of play and assist coaches in the development of WT as a distinct sport. In-depth analysis of the performance demands of WT is essential to improve training techniques. We predicted that WT players would hit more groundstrokes than net strokes and that there would be differences between winning and losing players. The aims of this study were to investigate male WT players' shot selection and how choice of shot affected performance and to compare winning and losing players on a per set basis.

\section{Material and Method}

\section{Sample}

Sixteen men's singles tennis matches were recorded during the Spanish Wheelchair Tennis Master Cup and subsequently analysed. The tournament was contested by the eight bestranked Spanish players; four of them were ranked in the top 100 of the International Tennis Federation (ITF) ranking, and the other four in the top 200. All the players who took part were training for two to three days a week and playing at least eight national or international tournaments a year at the time. The video recordings of matches were replayed on a monitor for computerised recording of their activity patterns. The ethics committee of the Royal 
Sánchez-Pay, A.; Torres-Luque, G., \& Sanz-Rivas, D. (2017). Stroke performance in high-level Spanish wheelchair tennis players. RICYDE. Revista internacional de ciencias del deporte, 48(13), 139-148. https://doi.org/10.5232/ricyde2017.04804

Spanish Tennis Federation approved this study, and all the subjects provided written informed consent to participation in advance.

\section{Procedure}

All tennis matches were played on the same type of hard indoor surface. All matches were played with a referee in accordance with international tennis rules (ITF, 2012). The matches were three-set matches with a ten-point super tiebreak played at the end of the third set. We did not analyse data from super tiebreaks.

All matches were filmed using a Panasonic HC- Panasonic HC-V700 wide-angle camera located in a corner of the court, outside of the fence in a position offering a view of the entire court. The cameras did not interfere with the game and could not be hit by tennis balls.

A specially designed spreadsheet (Table 1) based on those used in research on related racket sports studies (Torres-Luque, Ramírez, Cabello-Manrique, Pantelis, \& Alvero-Cruz, 2015; Juan-Campos, 2016) was used to code all shots. The data were obtained through the viewing of matches. All shots were coded using the coding scheme given below:

Table 1. Coding system used for a wheelchair tennis match analysis

\begin{tabular}{|l|l|}
\hline Score & "1": No Game Point Opportunity (NGO). "2": Game Point Opportunity (GO) \\
\hline Player & "1": Player 1. "2": Player 2 \\
\hline Stroke performed & $\begin{array}{l}\text { "1": } 1 \text { st Service*. "2": 2nd Service. "3": Forehand return. "4": Backhand return. } \\
\text { "5": Backhand slice return. "6": Forehand. "7": Backhand. "8": Backhand slice. } \\
\text { "9": Forehand approach. "10": Backhand approach. "11": Backhand slice } \\
\text { approach. "12": Forehand passing. "13": Backhand passing. "14": Backhand slice } \\
\text { passing. "15": Forehand volley. "16": Backhand volley. "17": Forehand lob. } \\
\text { "18": Backhand lob. "19": Smash. "20": Forehand drop shot. "21": Backhand } \\
\text { drop shot. "22": Other shots }\end{array}$ \\
\hline Stroke outcome & "1": error. "2": rally. "3": winner \\
\hline Player outcome & "1": win. "2": lose \\
\hline Set outcome & "1": win. "2": lose \\
\hline
\end{tabular}

* First service only was coded as rally or winner. No was coded as errors because that corresponded to second serve (double fault).

Score. Scores were encoded as non-game point opportunities (NGOs; e.g. 0-0, 15-0, 15-15, 40-40 etc.) or game point opportunities (GOs; e.g. 0-40, 40-15, 30-40, 40-30, 40-A etc.) according to tennis rules (ITF, 2012).

Player. Players were coded as player 1 or player 2 depending on which player made the action.

Shot selection. Shots were coded according to the technical descriptions of the Coaches Education and Research RFET Department (2015). The observers did not differentiate between flat shots and shots hit with topspin because this would have required biomechanical analysis, but they did differentiate between slice shots and flat or top spin shots on the basis of the movement performed.

Shots were further coded as: a) service: first serve or second serve; b) return: forehand return, backhand return or backhand slice return; c) groundstroke: forehand, backhand, backhand 
Sánchez-Pay, A.; Torres-Luque, G., \& Sanz-Rivas, D. (2017). Stroke performance in high-level Spanish wheelchair tennis players. RICYDE. Revista internacional de ciencias del deporte, 48(13), 139-148. https://doi.org/10.5232/ricyde2017.04804

slice, forehand approach, backhand approach, backhand slice approach, forehand passing shot, backhand passing shot, backhand slice passing shot, forehand lob, backhand lob, smash, forehand drop shot, backhand drop shot or other shots; d) net shot: forehand volley or backhand volley.

Shot outcome. The outcome of a shot was coded as error, rally or winner as follows: a) error: the ball hits the net, goes long or goes wide; b) rally: the ball bounces within the limits of the singles court and is hit by the opponent; 3 ) winner: the ball bounces within the boundaries of the court and the opponent does not hit it before it has bounced three times (Brody, 2006; ITF, 2012).

Point outcome. Point outcome was coded as win (if the player subsequently won the point) or lose.

Set outcome. Set outcome was coded 1 if the player won and 2 if he did not.

Data were collected through systematic observation in accordance with guidelines for observational research (Anguera, Blanco, Hernández-Mendo \& Losada, 2011). The two observers were experienced researchers and tennis coaches certified by the Royal Spanish Tennis Federation who had been trained to make observations. Intra-rater and inter-rater reliability were calculated. To enable the calculation of intra-rater reliability the observers coded a given set twice with a four-week interval between the two coding exercises. Intrarater was calculated using Cohen's kappa and the values were 0.97 and 0.93 for the two observers. Subsequently inter-rater reliability was calculated in terms of Cohen's kappa on the basis of independent coding of one match by both observers; values were very good $(>0.80)$ (Landis \& Koch, 1977) for all variables. Inter-rater reliability was lowest for shot selection (0.81). After the observers had been trained the matches to be analysed were distributed evenly between them.

\section{Statistical Analysis}

The sample of variables was obtained from 5.720 shots distributed over 16 matches. From the spreadsheet, data was exported to SPSS 21.00 (IBM Corp., Armonk, NY, USA) for analysis. Cohen's Kappa was used to calculate intra-rater and inter-rater reliability. From these data, percentage, mean, standard deviation and range were calculated. Z-tests were used to compare the differences between winning and losing player as well as differences between non-game point opportunities (NGO) and game-point opportunities (GO). Significance level was set at $\mathrm{p}<0.05$.

\section{Results}

Table 1 shows the values and distribution of each stroke and differences between winning and losing player for each set. The most frequently used shot is the forehand, used $34.97 \pm 18.07$ times per set, which represents $19.56 \%$ of all shots in a set. First and second serve are the second most common shots in a WT match, making up $16.47 \%$ and $13.23 \%$ of shots respectively. Table 2 also shows differences between winning and losing players. Winning players hit more first serves $(17.97 \% p<0.05)$ than losing players $(14.95 \%)$, whereas losing players hit more second serves $(14.29 \%$ vs. $12.19 \%)$, backhand slice approach shots $(0.60 \%$ vs. $0.14 \%)$ and forehand volleys $(1.30 \%$ vs. $0.52 \%)$. 
Sánchez-Pay, A.; Torres-Luque, G., \& Sanz-Rivas, D. (2017). Stroke performance in high-level Spanish wheelchair tennis players. RICYDE. Revista internacional de ciencias del deporte, 48(13), 139-148. https://doi.org/10.5232/ricyde2017.04804

Table 1. Descriptive tennis strokes used in a set and differences between winning and losing set players'.

\begin{tabular}{|c|c|c|c|c|c|}
\hline & & & & \multicolumn{2}{|c|}{ Z-test } \\
\hline & Mean & SD & $\%$ & Loser & Winner \\
\hline 1st Service & 29.44 & 7.79 & 16.47 & 14.95 & $17.97 *$ \\
\hline 2nd Service & 23.66 & 8.29 & 13.23 & 14.29* & 12.19 \\
\hline Forehand return & 21.59 & 10.39 & 12.08 & 12.64 & 11.53 \\
\hline Backhand return & 9.66 & 8.30 & 5.40 & 4.95 & 5.85 \\
\hline Backhand slice return & 13.25 & 7.17 & 7.41 & 7.41 & 7.42 \\
\hline Forehand & 34.97 & 18.07 & 19.56 & 19.69 & 19.44 \\
\hline Backhand & 19.38 & 15.29 & 10.84 & 11.23 & 10.45 \\
\hline Backhand slice & 15.16 & 11.34 & 8.48 & 8.21 & 8.74 \\
\hline Forehand approach & 1.81 & 2.09 & 1.01 & 0.95 & 1.08 \\
\hline Backhand approach & 0.38 & 0.55 & 0.21 & 0.28 & 0.14 \\
\hline Backhand slice approach & 0.66 & 1.07 & 0.37 & $0.60 *$ & 0.14 \\
\hline Forehand passing & 1.31 & 1.71 & 0.73 & 0.60 & 0.87 \\
\hline Backhand passing & 0.94 & 1.41 & 0.52 & 0.39 & 0.66 \\
\hline Backhand slice passing & 0.34 & 0.65 & 0.19 & 0.11 & 0.28 \\
\hline Forehand volley & 1.63 & 1.84 & 0.91 & $1.30 *$ & 0.52 \\
\hline Backhand volley & 1.59 & 1.54 & 0.89 & 0.95 & 0.84 \\
\hline Forehand lob & 0.41 & 0.61 & 0.23 & 0.21 & 0.24 \\
\hline Backhand lob & 0.69 & 0.82 & 0.38 & 0.39 & 0.38 \\
\hline Smash & 0.31 & 0.64 & 0.17 & 0.14 & 0.21 \\
\hline Forehand drop shot & 0.69 & 0.90 & 0.38 & 0.35 & 0.42 \\
\hline Backhand drop shot & 0.75 & 0.92 & 0.42 & 0.25 & 0.59* \\
\hline Other shots & 0.16 & 0.45 & 0.09 & 0.14 & 0.03 \\
\hline
\end{tabular}

$*=$ Significant differences $p<0.05$

Table 2 shows the distribution of each group of strokes (services, returns, groundstrokes and net strokes) and their relation to performance. Serves made up $29.7 \%$ of all points in a set. For every 2.71 service aces there were 11.89 double faults. Groundstrokes made up the majority of shots in a set (43.3\%) and the least frequent category of shot was net strokes $(2.1 \%)$. A wheelchair tennis player makes 10.6 winners and 19 errors per 100 shots.

Table 2. Relation between type of stroke and its performance.

\begin{tabular}{|l|c|c|c|c|}
\hline & $\begin{array}{c}\text { Error } \\
(\%)\end{array}$ & $\begin{array}{c}\text { Rally } \\
(\%)\end{array}$ & $\begin{array}{c}\text { Winner } \\
(\%)\end{array}$ & $\begin{array}{c}\text { Total } \\
(\%)\end{array}$ \\
\hline Services & 11.89 & 85.40 & 2.71 & $\mathbf{2 9 . 7}$ \\
\hline Returns & 21.98 & 66.43 & 11.59 & $\mathbf{2 4 . 9}$ \\
\hline Groundstrokes & 21.10 & 64.18 & 14.72 & $\mathbf{4 3 . 3}$ \\
\hline Net strokes & 43.22 & 33.05 & 23.73 & $\mathbf{2 . 1}$ \\
\hline Total & $\mathbf{1 9 . 0}$ & $\mathbf{7 0 . 4}$ & $\mathbf{1 0 . 6}$ & $\mathbf{1 0 0}$ \\
\hline
\end{tabular}


Sánchez-Pay, A.; Torres-Luque, G., \& Sanz-Rivas, D. (2017). Stroke performance in high-level Spanish wheelchair tennis players. RICYDE. Revista internacional de ciencias del deporte, 48(13), 139-148. https://doi.org/10.5232/ricyde2017.04804

Table 3 shows the differences between winning and losing players with respect to shot outcomes. Winning players made fewer errors than losing players on services, returns, groundstrokes and net strokes. They also made more winning shots on services, returns and groundstrokes. The greatest difference between winning and losing players was with respect to winning services $(80.4 \%$ vs. $19.6 \%$ respectively).

Table 3. Differences between winning (W) and losing (L) players in stroke performance.

\begin{tabular}{|l|c|c|c|c|c|c|}
\hline & \multicolumn{2}{|c|}{$\begin{array}{c}\text { Error } \\
(\%)\end{array}$} & \multicolumn{2}{c|}{$\begin{array}{c}\text { Rally } \\
(\%)\end{array}$} & \multicolumn{2}{c|}{$\begin{array}{c}\text { Winner } \\
(\%)\end{array}$} \\
\hline & Loser & Winner & Loser & Winner & Loser & Winner \\
\hline Services & 51.5 & 48.5 & 49.6 & 50.4 & 19.6 & 80.4 \\
\hline Returns & 54.0 & 46.0 & 50.4 & 49.6 & 40.0 & 60.0 \\
\hline Groundstrokes & 58.7 & 41.3 & 49.5 & 50.5 & 37.5 & 62.5 \\
\hline Net strokes & 62.7 & 37.3 & 64.1 & 35.9 & 53.6 & 46.4 \\
\hline
\end{tabular}

Table 4 compares the distribution of strokes on non-game point opportunities (NGOs) and game point opportunities (GOs). The only difference is in use of backhand slice approaches, which were more frequent on NGOs than GOs $(p<0.05)$.

Table 4. Differences between no game point opportunity (NGO) and game point opportunity (GO).

\begin{tabular}{|l|c|c|}
\hline & $\begin{array}{c}\text { NGO } \\
(\%)\end{array}$ & $\begin{array}{c}\text { GO } \\
(\%)\end{array}$ \\
\hline 1st Service & 16.62 & 15.95 \\
\hline 2nd Service & 13.07 & 13.77 \\
\hline Forehand return & 12.39 & 11.06 \\
\hline Backhand return & 5.17 & 6.17 \\
\hline Backhand slice return & 7.61 & 6.77 \\
\hline Forehand & 19.24 & 20.62 \\
\hline Backhand & 10.73 & 11.21 \\
\hline Backhand slice & 8.24 & 9.26 \\
\hline Forehand approach & 1.02 & 0.98 \\
\hline Backhand approach & 0.25 & 0.08 \\
\hline Backhand slice approach & $\mathbf{0 . 4 6 *}$ & 0.08 \\
\hline Forehand passing & 0.82 & 0.45 \\
\hline Backhand passing & 0.55 & 0.45 \\
\hline Backhand slice passing & 0.20 & 0.15 \\
\hline Forehand volley & 0.82 & 1.20 \\
\hline Backhand volley & 0.93 & 0.75 \\
\hline Forehand lob & 0.23 & 0.23 \\
\hline Backhand lob & 0.46 & 0.15 \\
\hline Smash & 0.23 & 0.00 \\
\hline
\end{tabular}


Sánchez-Pay, A.; Torres-Luque, G., \& Sanz-Rivas, D. (2017). Stroke performance in high-level Spanish wheelchair tennis players. RICYDE. Revista internacional de ciencias del deporte, 48(13), 139-148. https://doi.org/10.5232/ricyde2017.04804

\begin{tabular}{|l|c|c|}
\hline Forehand drop shot & 0.43 & 0.23 \\
\hline Backhand drop shot & 0.48 & 0.23 \\
\hline Other shots & 0.05 & 0.23 \\
\hline
\end{tabular}

\section{Discussion}

The aim of this study was to analyse shots used in wheelchair tennis (WT) matches and compare the performance of the winning and losing players on a per set basis. Improving understanding of the performance demands of WT helps to improve training methods and provides information about differences between winning and losing performances.

Services made up almost $30 \%$ of all shots in a set (Table 3 ). This result is in line with the distribution of shots in CT, in which the service is also the most frequent shot (Johnson \& McHugh, 2006). The high percentage of services in WT could be due to the small number of shots per rally, around 3 or 4 shots per point (Bullock \& Pluim, 2003; Sanchez-Pay, SanzRivas, \& Torres-Luque, 2015; Veltmeijer, Pluim, Thijssen, Hopman, \& Eijsvogels, 2014). Winning players hit proportionally more first serves and proportionally fewer second serves than losing players (Table 2) and they also hit more winners and fewer errors than losing players Table 4). These differences could be due to differences in impairment and other player characteristics as service velocity is related to type of impairment (Cavedon, Zancanaro, \& Milanese, 2014). These results are in line with observations of women's WT (Sanchez-Pay, 2015a) and CT matches (Katić, Milat, Zagorac, \& Đurovic, 2011). WT players hit 2.7 aces for every 11.8 double faults (Table 3 ), or 4.3 double faults per ace. These results are consistent with other studies of WT, which also reported that there were more double faults than aces (Sanchez-Pay et al., 2015a,b), but they contrast with the statistics for CT matches (Brown \& O’Donoghue, 2008; Cross \& Pollard, 2009). Taken together these studies provide support for the notion that it is more difficult to hit an ace in WT than in CT.

The second shot in a tennis point is the return. In our data returns made up $25 \%$ of all shots played in a set (Table 3). Forehand returns (12.08\%) and backhand returns (12.81\%) account for similar percentages of WT players' shots (Table 2). This contrasts with a study of CT, which reported that there were more backhand returns than forehand returns (Johnson \& McHugh, 2006). This difference in findings may be due to the differences in the level of the players who participated in the two studies. Johnson and McHugh (2006) analysed Grand Slam tournament (elite) players whereas this study used national-level players and there is some evidence that players' shot selection is influenced by their experience and level. Although in this study the percentages of forehand and backhand returns were similar, backhand slice returns were used more often (7.41\%) than flat or topspin backhand returns $(5.40 \%)$. When returning the serve WT players make more than twice as much errors than winners (Table 3 ) and winning players hit more winning returns than do losing players (Table 4). The differences between winning and losing players are in line with the result of an earlier study of women's WT matches (Sanchez-Pay et al., 2015a) and may be due to winning players having better tactical awareness when it comes to shot execution (direction, distance, spin and power) and wheelchair movement (recoveries, movement speed and position), which are aspects of performance that were not evaluated in this study.

Groundstrokes make up more than $43 \%$ of all shots in a set (Table 3). Similar use is made of both forehand (19.56\%) and backhand shots (19.32\%), but backhand slice is used less than flat or topspin backhand shots (Table 2). In women's WT matches the shot used most frequently by winning players is the forehand and winning players hit more winning 
Sánchez-Pay, A.; Torres-Luque, G., \& Sanz-Rivas, D. (2017). Stroke performance in high-level Spanish wheelchair tennis players. RICYDE. Revista internacional de ciencias del deporte, 48(13), 139-148. https://doi.org/10.5232/ricyde2017.04804

forehands than losing players do (Sanchez-Pay et al., 2015a). Overall, we found that winning players hit more winning groundstrokes $(62.5 \%)$ than losing players $(37.5 \%)$ (Table 4$)$, thus corroborating the results of earlier studies (Sanchez-Pay et al., 2015a). Groundstrokes made up $43.3 \%$ of all shots (Table 3 ) and forehand and backhand shots made up more than $38 \%$ of all strokes in a set (Table 2). These strokes may be the two most important stokes in WT and this finding should be taken into consideration by coaches when designing exercises.

Net shots are the category of shot used least frequently by WT players, accounting for just $2.1 \%$ of all shots (Table 3). The proportion of winner net strokes is highest of any of the type of stroke $(23.73 \%)$, although also highest for error performance (43.22\%) (Table 3). Net shots are less common in WT than in CT (Brown \& O'Donoghue, 2008), perhaps because WT players are seated in chairs and thus lower to the ground than CT players, which makes it easier to lob them. WT players also move more slowly, making maintenance of a good court position and changes of direction more difficult. Losing players used forehand volleys more frequently than winning players $(p<0.05)$ (Table 2$)$, which may explain why net shots is the only shot category in which losing players had the higher percentage of winning strokes $(53.6 \%$ vs. $46.4 \%)$ (Table 4$)$, although the difference between winning and losing players was greatest with respect to errors $(62.7 \%$ vs. $37.3 \%)$ (Table 4$)$.

The scoring system used in tennis means that not all points have the same importance. Some points give one player the opportunity to win a game. In CT game action is not identically distributed over the course of the match, and changes depending on game point situation (Klaassen \& Magnus, 2001; Knight \& O'Donoghue, 2012). We found that use of the backhand slice approach shot differed $(p<0.05)$ GOs and NGOs (Table 5). The backhand slice approach is not a common shot in WT matches, making up only .46\% of shots on NGOs and $.08 \%$ on GOs (Table 5). These findings suggest that the game action is not as unevenly distributed in WT as in CT (Klaassen \& Magnus, 2001; Knight \& O'Donoghue, 2012).

This study provides important information for coaches about what kinds of shot are successful in competition, but it has some important limitations. First, the choice of shot and outcome of hitting a particular shot are related to the positions of the players on court and we did not evaluate this. Second, our data relate to WT played on hard courts. It would be interesting to compare shot selection and outcomes on different surfaces and to look at the impact of different types of impairment.

\section{Conclusion}

Overall WT players make more errors (19\%) than they hit winners $(10.6 \%)$. Together service and return shots make up about $55 \%$ of all shots in a point and net play is infrequent $(2.1 \%$ of shots). In a given set the winning player hits more winning serves, returns and groundstrokes than the losing player. The only category of shot in which the losing player is more successful is net shots, although losing players also make more errors at the net than winning players. These results and the differences between the performance of winning and losing players should be taken into consideration by WT coaches when designing training programmes. 
Sánchez-Pay, A.; Torres-Luque, G., \& Sanz-Rivas, D. (2017). Stroke performance in high-level Spanish wheelchair tennis players. RICYDE. Revista internacional de ciencias del deporte, 48(13), 139-148. https://doi.org/10.5232/ricyde2017.04804

\section{References}

Anguera, M. T.; Blanco, A.; Hernández-Mendo, A., y Losada, J. L. (2011). Diseños observacionales: ajuste y aplicación en psicología del deporte. Cuadernos de psicología del deporte, 11(2), 63-76.

Brody, H. (2006). Unforced errors and error reduction in tennis. British Journal of Sports Medicine, 40(5), 397-400.

https://doi.org/10.1136/bjsm.2005.023432

Brown, E., \& O'Donoghue, P. (2008). Gender and surface effect on elite tennis strategy. ITF Coaching \& Sports Science Review, 46(15), 9-11.

Bullock, M., \& Pluim, B. (2003). Wheelchair tennis and physical conditioning. ITF Wheelchair Tennis Coaches Review, 3(9), 2-10.

Bullock, M., \& Sanz, D. (2010). Wheelchair tennis in 2010. ITF Coaching \& Sports Science Review, 50, 30-31.

Juan-Campos, J. M. (2016). Criterios de rendimiento en el último golpe en tenistas profesionales. Trabajo fin de master. Universidad de Jaén.

Cavedon, V.; Zancanaro, C., \& Milanese, C. (2014). Kinematic analysis of the wheelchair tennis serve: Implications for classification. Scandinavian Journal of Medicine \& Science in Sports, 24(5), 381-388. https://doi.org/10.1111/sms.12182

Cross, R., \& Pollard, G. (2009). Grand Slam men's singles tennis 1991-2009. Serve speeds and other related data. ITF Coaching \& Sports Science Review, 16(49), 8-10.

Filipčič, A.; Caks, K., \& Filipčič, T. (2011). A comparison of selected match characteristics of female tennis player. Kinesiologia Slovenica, 17(2), 14-24.

Filipčič, T., \& Filipčič, A. (2006). Analysis of tennis strokes in wheelchair tennis. ITF Wheelchair tennis coaches review, 14, 17-21.

Filipčič, T., \& Filipčič, A. (2009). Analysis of movement velocity and distance covered in wheelchair tennis. Kinesiologia Slovenica, 15(2), 25-32.

Hughes, M. (1998). The application of notational analysis to racket sports. In A. Lees, I.W. Maynard, M. Hughes, \& T. Reilly (eds.), Science and Racket Sports II (pp. 211220). London, E\&FN Spon.

ITF. (2012). Rules of tennis. London: ITF.

Johnson, C. D., \& McHugh, M. P. (2006). Performance demands of professional male tennis players. British Journal of Sports Medicine, 40(8), 696-699. https://doi.org/10.1136/bjsm.2005.021253

Katić, R.; Milat, S.; Zagorac, N., \& Đurović, N. (2011). Impact of Game Elements on Tennis Match Outcome in Wimbledon and Roland Garros 2009. Collegium Antropologicum, 35(2), 341-346.

Klaassen, F. J., \& Magnus, J. R. (2001). Are points in tennis independent and identically distributed? Evidence from a dynamic binary panel data model. Journal of the American Statistical Association, 96(454), 500-509. https://doi.org/10.1198/016214501753168217

Knight, G., \& O'Donoghue, P. (2012). The probability of winning break points in Grand Slam men's singles tennis. European Journal of Sport Science, 12(6), 462-468. https://doi.org/10.1080/17461391.2011.577239

Landis, J. R., \& Koch, G. G. (1977). The measurement of observer agreement for categorical data. Biometrics, 159-174.

https://doi.org/10.2307/2529310 
Sánchez-Pay, A.; Torres-Luque, G., \& Sanz-Rivas, D. (2017). Stroke performance in high-level Spanish wheelchair tennis players. RICYDE. Revista internacional de ciencias del deporte, 48(13), 139-148. https://doi.org/10.5232/ricyde2017.04804

Martínez-Gallego, R.; Guzmán, J. F.; James, N.; Pers, J.; Ramón-Llin, J., \& Vuckovic, G. (2013). Movement characteristics of elite tennis players on hard courts with respect to the direction of ground strokes. Journal of Sports Science \& Medicine, 12(2), 275.

O'Donoghue, P. (2012). Break points in Grand Slam men's singles tennis. International Journal of Performance Analysis in Sport, 12(1), 156-165.

Reid, M.; Elliott, B., \& Alderson, J. (2007). Shoulder joint kinetics of the elite wheelchair tennis serve. British Journal of Sports Medicine, 41(11), 739-744. https://doi.org/10.1136/bjsm.2007.036145

Sánchez-Pay, A.; Sanz-Rivas, D., \& Torres-Luque, G. (2015). Match analysis in a wheelchair tennis tournament. International Journal of Performance Analysis in Sport, 15(2), 540-550.

Sánchez-Pay, A.; Palao, J. M.; Torres-Luque, G., \& Sanz-Rivas, D. (2015b). Differences in set statistics between wheelchair and conventional tennis on different types of surfaces and by gender. International Journal of Performance Analysis in Sport, 15(3), 1177-1188.

Sánchez-Pay, A.; Torres-Luque, G.; Cabello-Manrique, D.; Sanz-Rivas, D., \& Palao, J. M. (2015a). Match analysis of women's wheelchair tennis matches for the Paralympic Games. International Journal of Performance Analysis in Sport, 15(1), 69-79.

Torres-Luque, G.; Ramírez, A.; Cabello-Manrique, D.; Pantelis, N., y Alvero-Cruz, J (2015). Match analysis of elite players during paddle tennis competition. International Journal of Performance Analysis in Sport, 15, 1135-1144.

Sindall, P.; Lenton, J. P.; Tolfrey, K.; Cooper, R. A.; Oyster, M., \& Goosey-Tolfrey, V. L. (2013). Wheelchair tennis match-play demands: effect of player rank and result. International Journal of Sports Physiology and Performance, 8(1), 28-37. https://doi.org/10.1123/ijspp.8.1.28

Veltmeijer, M.; Pluim, B.; Thijssen, D.; Hopman, M., \& Eijsvogels, T. (2014). Thermoregulatory responses in wheelchair tennis players: a pilot study. Spinal Cord, 52(5), 373-377.

https://doi.org/10.1038/sc.2014.27 